\title{
MANIPULACIJA SAVREMENIM KOMUNIKACIJAMA U SVRHU MOBINGA
}

\section{MANIPULATION WITH MODERN COMMUNICATIONS IN SERVICE OF MOBBING}

\section{Radmila Ćurčić}

Naftna industrija Srbije Novi Sad, Narodnog fronta 12, Novi Sad, Republika Srbija

\section{Vladimir Prebiračević}

Vojvođanski antimobing centar, Pariske Komune 40, Novi Sad, Republika Srbija

\author{
Nataša Vasić \\ Vojvođanski antimobing centar, Pariske Komune 40, Novi Sad, Republika Srbija \\ (C) MESTE NGO
}

\begin{abstract}
Sažetak:
Društveni život počiva na komunikaciji. To je veoma osetljivo područje na koje menadžment mora posebno da obraća pažnju, kako ne bi dolazilo do mobinga. Zlostavljanje na radnom mestu, pogotovu psihološko, društveno je potpuno neprihvatljivo. Poslednjih godina posvetila se velika pažnja prevenciji $i$ borbi protiv mobinga, kao što su mnoge zemlje rešavale pravna pitanja u vezi sa ovim pojmom. Mobing kao zlostavljanje na radnom mestu počinje komunikacijom, koja je neetička i patološka. Da bi kasnije presasla u ponižavanje, omalovažavanje, vređanje a nekad i fizičko nasilje. Zloba kao pritajeni motiv, ima za cilj eliminaciju radnika sa posla, a posledice ostaju ceo život. Društvo tek treba da se pozabavi ovim fenomenom.
\end{abstract}

\section{Ključne reči:}

mobing, manipulacija, mober, komunikacije, savremene komunikacije

\begin{abstract}
:
Social life is based on communication. It is highly sensitive area for management attention in order to avoid mobbing. Bullying at work place, psychological bullying in particular, is socially unacceptable. In recent years a great attention has been devoted to prevention of mobbing, with many countries introducing new legal regulations in connection to mobbing. Mobbing as a form of abuse at work begins with communication unethical and pathological, which then leads to humiliation, degradation, insults and sometimes even physical violence. Malice as a hidden motive has a purpose to eliminate worker from the work place, and the consequences remain for life. The society is yet to deal with this phenomenon.
\end{abstract}

Adresa autora zaduženog za korespodenciju :

Vladimir Prebiračević

豐” vamc021@gmail.com
Keywwords: mobbing, manipulation, person who is mobbing, communications, modern communications 


\section{Uvod}

Prvo šta odvaja čoveka kao društveno biće od životinja jeste komunikacija. Da bi čovek funkcionisao sa drugim jedinkama veoma je bitna zdrava komunikacija. Proces komuniciranja je veoma često od presudnog značaja u poslovnim sferama. Konstruktivan dijalog, veština slušanja, kultura uvažavanja sagovornika, kao i poštovanje istog, samo su neki od činilaca veštine komuniciranja i preduslovi korektnog poslovnog odnosa.

U međuljudskim komunikacijama često može doći do nesporazuma, koji veoma često izazivaju konflikte. Upravo je to siva zona koja ostavlja otvorena vrata mnogim poslodavcima da vrše teror nad svojim zaposlenima. lako manipulacija, kao jedan od poslovnih poteza kojima se neretko pretpostavljeni služe, stoji usko uz svako poslovanje; danas je mnogo pažnje usmereno ka iskorenjivanju takve loše navike $i$ ideologije biznismena. Desna ruka svake manipulacije je mobing, što uvek treba imati na umu.

lako nauka, tehnika i tehnologija svakodnevno napreduju, činjenično stanje da je spona svakom procesa, kao i žila kucavica, ipak komunikacija. U tom smislu je potrebno više pažnje posvetiti zaposlenima, jer oni nisu, kao ranije što su bili, samo pasivni posmatrači i broj u kadrovskoj službi. Kako je jedan od glavnih elemenata svakog uspešnog menadžmenta upravljanje, upravo na tome je potrebno posebno raditi. Upravljanje komunikacijama je idejni preduslov profitabilne kompanije sa zdravom klimom unutar iste. Cilj je umanjiti neizvesnost i konfliktne situacije, čime bi se podsticala kooperativnost a umanjila nezainteresovanost $\mathrm{i}$ ankcioznost. Kad je dobro razvijen timski duh i stvoren osećaj pripadnosti, saradnja među zaposlenima je na višem nivou; a time se prikazuje i ocena menadžmenta firme. Dobar menadžment znači rad sa ljudima, razvijanje saradnje i kulture dijaloga uz razmenu mišljenja.

lako mobing postoji od kada je sveta i veka, kroz istoriju je pasivno aktivna agresija bila legitimno prihvaćena i sprovođena. Svako istorijsko i praistorijsko razdoblje imalo je svoje primere ugnjetavanja $i$ iskorištavanja ljudskih kapaciteta; a sve u cilju postizanja većeg profita i priliva novca. To svakako ne treba prihvatati kao izgovor, jer svako ima pravo na svoju ličnu slobodu, prava, dostojanstvo i integritet.

Mobing kao pojam pojavljuje se tek poslednjih dvadesetak godina, ali pravi akcenat na borbu protiv vršenja agresije nad zaposlenima tek treba da se dogodi. Usled krize ljudi nisu u mogućnosti da se bore za svoja prava iz prostog razloga što se bore za egzistenciju i žele da sačuvaju i takav posao kakav imaju. Trenutna situacija, nažalost, ide u korist moberima, prvenstveno jer pravna pitanja $u$ mnogim zemljama na tu temu nisu rešena, a sa druge strane zaposleni potpadaju pod njihovu milost i nemilost. Ostaje da se vidi šta donosi budućnost. Za početak mere prevencije svakako da se moraju sprovoditi, a na prvom mestu je bolja informisanost i povećanje svesti zaposlenih o mobingu i kako se od njega braniti i zaštiti.

\section{Manipulacija komunikacija}

Korišćenje komunikacijskih veština sa svrhom manipulacije drugima nije retka pojava, baš naprotiv. Pobornici ideje korišćenja komunikacije za upravljanje zaposlenima služe se svim mogućim sredstvima kako bi ostvarili svoj primarni cilj, a to je naterati druge da rade ono šta manipulatori žele. Način na koji se ovakav proces ostvaruje prvenstveno se postiže ili ulagivanjem ili uterivanjem straha radnicima. Veoma je tanka granica između korišćenja komunikacijskih tehnika zarad poboljšanja odnosa unutar firme $i$, sa druge strane, $u$ svrhu vršenja uticaja na druge kako bi ta osoba činila ono šta mober želi, uglavnom nesvesna namera manipulatora bez mogućnosti opiranja.

Psiholozi savetuju da je čovekova psiha vrlo složena i kompleksna, ali se takođe i slažu da je jedan od bitnih elemenata ljudskog karaktera upravo uobrazilja. Upravo zbog toga se postavlja pitanje koliko je sam proces manipulacije krivica manipulatora i/ili osobe koja dozvoljava da se njome manipuliše. Kao oblik ponašanja, manipulacijom se ljudi služe kako bi stvari okrenuli u svoju korist, ili privoleli nekoga da čini radnje zarad sopstvenih ciljeva. lako često manipulativnost ne mora biti štetna i zlonamerna ${ }^{1}$, ipak je to vrsta perfidne igre, gde karte nisu otvorene niti je iskrenost jedan od činilaca takvog iskorištavanja.

\footnotetext{
${ }^{1}$ Sama manipulacija znači nečim vešto rukovati, ne zlonamerno upotrebljavati
} 
Manipulacija se definiše kao oblik ponašanja „koji se svodi na tendenciju da se događaji prikazuju na takav način da se druga osoba navodi na postupke koji služe ličnoj koristi“ (Popić, 2012). lako tako ne izgleda, ona služi za uspostavljanje kontrole, što se najčešće postiže ucenama, uterivanjem straha $u$ kosti, uslovljavanjima ili, pak, pretnjama. Činjenica stoji da je strah jedan od najvećih motivatora; time je vladavina strahom drugo ime za manipulativni čin. Međutim, postoji i benigniji način vršenja manipulacije, a to je udeljivanje lažnih komplimenata u manipulativne svrhe ${ }^{2}$, odnosno ulagivanje. lako komplimenti sami po sebi nisu opasni, prijatnost koji izazivaju in čini primamljivim. Manipulativci in dele „šakom i kapom“, i počinju da zvuče toliko ubedljivo da osobe sa kojima manipulišu, pre ili kasnije, počinju da veruju u ono šta čuju. Tako se njima $i$ lako ovladava, prosto se prepuste i počinju da menjaju svoje ponašanje. Upravo zbog toga je ovakav tip manipulacije krajnje opasan.

Manipulacija, ili kontrola uma, je veoma osetljivo psihološko područje. Termin "manipulacija“ nastao je spojem dve latinske reči: manus - ruka i manipulus - pregršt, šaka, što dalje govori da manipulisati znači upravo rukovati ili upravljati nečim, i to sa određenom namerom ili ciljem. Ako se posmatra $u$ kontekstu ljudskih odnosa i procesa komunikacije, manipulatisvnost je onda pokušaj upravljanja nekim, odnosno ponašanjem tog nekog, na načine na koji in ta osoba nije ni svesna. S tim u vezi je manipulatora najbolje objasniti kao „vuka u jagnjećoj koži“. I to po usklađenoj šemi - jedno priča, drugo radi, treće misli.

\subsection{Sredstva manipulacije}

Termin manipulacija nije jedinstven, u smislu da se koristi za objašnjavanje samo jedne vrste menjanja nečijeg stava, misli, osećanja i ponašanja. Na mnogo načina se može manipulisati drugima, tako se i raspoznaju drugačija sredstva manipulacije (Popić, 2012):

1. Lična uvreda ili vređanje - ovde se osobe veoma dobro poznaju. Koristeći slabe tačke osobe, vređanjem i ponižavanjem manipulator čini da izmanipulisani menja svoje ponašanje i čini ono šta se od njega zahteva ili traži.

${ }^{2}$ Postoji mnogo osoba koje prosto vape za komplimentima, i
njima se lako upravalja i rukuje

${ }^{2}$ Postoji mnogo osoba koje prosto vape za komplimentima, i
njima se lako upravalja i rukuje

2. Pretnja i ucene - pretiti je uslovno posledičan proces, dok je ucenjivanje opet najčešće emotivnog karaktera, sa primesama uslovljavanja ili zlobe.

3. Laskanje - o ovome je već bilo reči. To je vid stvaranja lažne slike, prvenstveno prenaglašenom naklonošću, dušebrižničkim izjavama i privid kvazi prijateljstva. Manipulator slatkorečivošću razvija lažnu prisnost, a kasnije koristi sve u svoju korist.

4. Izigravanje žrtve - pored straha jedan od najjačih pokretača drugih na akcije i reakcije je izazivanje sažaljenja. Manevr gde manipulator predstavlja sebe kao bespomoćnu žrtvu i time izaziva kod drugih da iz sažaljenja čine razne stvari, ili odstupaju od svojih odluka.

5. Stvaranje osećaja krivice - kao i sažaljenje, slična sprega u izazivanju reakcija.

6. Interes „ti meni, ja tebi“ - uvek tu da pomognu, sami se ili ponude ili samoinicijativno učine sve šta treba, ali podmuklo očekuju zauzvrat više nego što su dali, i žele da od ljudi načine svoje robove, gledajući u svemu puki interes.

7. Poricanje - klopka koju manipulator napravi tako što izvrće stvari, menja podatke, tera vodu na svoju vodenicu, pravi se blesav i ubeđuje svoju žrtvu kako crno nije crno, do te mere da se osoba izgubi i počinje da preispituje sebe i svoju pamet.Tehnika reinženjering pristupa

\subsection{Pasivna agresija}

Agresija sama po sebi doprinosi razvijanju osećanja straha. Međutim, pored fizičke agresije, postoji i „benignija“ vrsta, a to je pasivna agresija, ili bolje reći vršenje psihičke torture. Možda je najbolje objasniti kao stanje pred fizički obračun, ali tako prikrivena i zamaskirana, pasivna agresija je mnogo destruktivnija i pogubnija po emotivno i psihičko zdravlje zaposlenih. Kada se manipulator vrši ovom „tehnikom“, sve govori u prilog činjenici da se radi o krajnje podmukloj osobi, kojoj su oružje sarkazam, ironija, dvosmislenost i sve slično tome. Sve čini u pokušaju da zbuni protivnika, kako bi eliminisali bilo kakav vid konfrontacije. Vešti na rečima, izvrću stvari maestralno, $u$ isto vreme napadaju i brane se, a sve u pitomom i ležernom tonu. Poenta ovakvog ponašanja je preokrenuti sve u sopstvenu korist, a sagovornika napraviti ludim usled njegove zbunjenosti. Može da se kaže da „pasivno agresivna osoba prepušta odgovornost za sukob sagovorniku 
koji je, uostalom, zaista „naseo“ na manipulaciju komunikacijom" (Gvozdić, 2010); pošto čak i u slučaju sukoba ili svađe, izmanipulisana osoba izvlači deblji kraj kao osoba koja burno reaguje, ili još gore, ima problem s besom.

Prostor delovanja za pasivne agresivce je širok, pogotovu kad postaje jasno da oni nikad nisu krivi, i sve ukazuje na to da stvari čine i rade nesvesno. $U$ tome je upravo i stvar, oni zaista ne veruju u ideju da čine bilo šta loše ili nažao nekome. Psihološki profil ovakvih ljudi obitava odbacivanjem i izbegavanjem bilo kakve odgovornosti, a funksionišu u svim sistemima kao „ribe u vodi“. Međutim, druga strana medalje je autodestruktivnost ovakvih osoba. Takvi ljudi su puni nezadovoljstva i zavisti, emotivno su neispunjeni, energetski su vampiri, sumnjaju u sve i sva, i imaju veoma izražen negativan pogled na život. Zajedljive komentare plasiraju kako bi stvarali sukobe i služe se ogovaranjima u cilju potkupljivanja i okretanja ljudi na svoju stranu. Imaju veoma razrađen sistem manipulacije komunikacijom, ali in karakteriše i nizak nivo samopoštovanja, što pre ili kasnije dođe do izražaja.

\section{Mobing kao vid patološke komunikacije}

lako zlostavljanje na radu postoji od kad postoji i čovečanstvo, sam pojam mobinga u medijima $i$ literaturi postao je bitan predmet izučavanja tek 80tih godina prošlog veka. Želja za vlašću, zavist, ljubomora i nesigurnost, samo su neki od razloga zašto tolazi do ovog fenomena. Razlog zašto se izučava je jasan „zato što se mobingom ugrožava ugled, čast, ljudsko dostojanstvo; što su temelji čovekove ličnosti ili osnovne ljudske vrednosti“ (Anon, Mobing i kako ga sprečiti Priručnik za regionalne poverenike UGS "Nezavisnost", 2012).

Zlostavljanja ima u svakoj sferi; počevši od javnog sektora, državnih i privatnih firmi, na fakultetima, u školama, pozorištima, koncertnim halama i svim profesijama. Time je jasno da nasilje i šikaniranje trpe svi: nekvalifikovani radnici isto koliko i nepismeni, visoko obrazovani, umetnici, doktori, profesori, i tako dalje. Mobing ne bira, jer je u njegovoj srži primitivizam i patologija. Takav fenomen je medicinsko-socijalni problem, koji se može uočiti još kod životinja, u sistemu prirodne selekcije i zakona čopora.

Mobing, ako se definiše kao nasilje na radnom mestu, počinje u domenu komunikacije, a posledice koje ostavlja su psihološke prirode. Zbog toga se često u literaturi objašnjava i kao psihološko maltretiranje, psihičko zlostavljanje ili teror. To je „specifičan oblik ponašanja i patološka (neprijateljska i neetička) komunikacija na radnom mestu“ (Anon, 2010), nasrtaj na nečiji ugled i čast; sa ciljem ponižavanja, eliminacije ili zlostavljanja druge osobe. To je danas „kompleksna, široko rasprostranjena i narastajuća pojava ${ }^{3}$, koja ima pogubne posledice na radnu snagu, psihofizičko zdravlje pojedinca, socijalno okruženje pojedinca i kompletnu zajednicu“ (Kondić \& dr, 2011). U suštini radi se o iživljavanju mobera zbog ličnih problema, komplekasa i sopstvene nesigurnosti. Zbog toga žrtva mobinga zaista može biti bilo ko, bez obzira na pol, godine, veru, obrazovanje, izgled ili materijalno stanje.

\subsection{Istorijat izučavanja pojave mobinga}

Mobing je verovatno isprva nastao iz želje za profitom od strane poslodavaca, verujući da će stvarajući strah kod zaposlenih pospešiti njihovu profuktivnost. Međutim, vremenom se stvar otrgla kontroli, te su danas psihička maltretiranja i pasivno nasilje postali uočljiviji nekog ikada ranije. Što je proporcionalan razlog da se termin mobing toliko pojavljuje u javnosti i medijima, na svetskom nivou.

Prvi naučnik koji se bavio izučavanjem pojave zlostavljanja je švedski psiholog nemačkog porekla dr Heinz Leymann. Još početkom 60-tih godina bavio se istraživanjem neprijateljskog ponašanja dece u školama ${ }^{4}$. Ovakav vid psihoterora kasnije je uočavao i u odnosima među odraslima, posebnu pažnju mu je privuklo ponašanje zaposlenih na radnom mestu. On je prvi i ustanovio sam termin, dajući ime mobing za ovakvu pojavu, što je preuzeo iz etologije, odnosno studije kojom se bavio Konrad Lorenz, opisujući ponašanje nekih vrsta životinja (Kostelić-Martić, 2005). U čoporu se životinje udružuju u grupu, u želji da izbace slabijeg člana, organizovano ga napadaju i izbacuju iz zajednice, nekad ga terajući u smrt.

Leymann je bio i ostao svetski priznat stručnjak i ekspert u polju mobinga. Pisao je gomile stručnih tekstova baveći se ovim fenomenom. Čak je i

\footnotetext{
${ }^{3}$ Istraživanja sprovedena u svetu pokazuju statistiku da je u SAD svaki četvrti ranik izložen mobingu, u Velikoj Britaniji svaki osmi, a u Evropi čak 15\% zaposlenih su žrtve mobinga. (Anon, Mobing - istina o kojoj se malo govori, 2009)

4 Eng. Bullying - odrasla deca zlostavljaju, odnosno svakodnevno maltretiraju mlađe i manje od sebe
} 
napisao enciklopediju mobinga, a prvi je osnovao $\mathrm{i}$ kliniku za pomoć žrtvama mobinga. U svojim tekstovima upozoravao je koliko je mobing štetan ne samo za pojedinca, nego i za društvenu zajednicu u celini, kao i pojedinačne nacionalne ekonomije, ukazujući da je mobing veliki trošak i gubitak novca. Evo nekih od aspekata definicije koju je dao upravo dr Heinz, „mobing je vrlo neprijateljska i neetična komunikacija, ciljno usmerena i planirana, postoji učestalost u dužem vremenskom razdoblju i ima vrlo jasan cilj: uništiti žrtvu, tačnije uzrokovati mentalne psihosomatske i socijalne posledice" (KostelićMartić, 2005).

Laymannova istraživanja dovela su do toga da se u okviru Ustava zemalja počinju stvarati zakoni i podzakonske akte o radnom okruženju i prihvatljivo neprihvatljivog ponašanja na poslu i prema drugim zaposlenima. Skandinavske zemlje su začetnice ovog pokreta i dan danas prednjače u pogledu zaštite od mobinga i mera prevencije ${ }^{5}$.

\subsection{Definicija mobinga}

Naziv mobing potiče iz engleskog jezika. I to od više vrsta reči, od (Anon, Šta je mobing?, 2011):

- Glagola to mob - nasrnuti u masi, bučno navaliti na nekog;

- Imenice mob - rulja, gomila, bagra, masa, ološ, svetina; i

- Izraza mobbish - prostački, grub, vulgaran

Od sih ovih reči i izraza, nastao je termin mobing, kao opis psihološkog maltretiranja na radnom mestu. U zemljama englesko-govornog područja dugo se koristio termin bullying, ali se on više odnosio na maltretiranje dece, odnosno fizičko nasilje u školama. Stoga ovaj termin nije bio opšte prihvaćen, jer se pod mobingom misli prvenstveno na suptilniji psihološki teror i maltretiranje odraslih na radnom mestu. Osim ta dva, u Americi se koristi još i termini work abuse i/lil employee abuse.

\footnotetext{
${ }^{5}$ Poražavajuća statistika mobinga u svetu govori da čak $97 \%$ ljudi smatra da se premalo govori o temi i pojavi mobinga, $84 \%$ da je bilo na neki način mobingovano od strane kolega, $45 \%$ oseća psihičke probleme zbog preopterećenosti poslom, 35\% poslodavaca nikad ne bi zaposlilo homoseksualca, 28\% kaže da im stres na poslu ugrožava zdravlje, u Švedskoj i Nemačkoj $20 \%$ samoubistava je u konekciji sa mobingom. Najviše zlostavljanja je u državnim organima i upravama $14 \%$, dalje slede školstvo i zdravstvo $12 \%$, transport i komunikacija, hotelijerstvo i restorani po $12 \%$, trogovina $9 \%$, građevinarstvo $5 \%$, poljoprivreda $3 \%$. (Anon, Mobing u svetu, 2011)
}

Mobing trajno remeti odnose među ljudima na radnom mestu, i ostavlja dugoročne posledice. Prema svetskim merilima, da bi se utvrdilo postojanje mobinga bitan je faktor vreme. Pojedinac mora biti izložen mobingu učestalo (barem jednom sedmično) i u dužem intervalu (najmanje 6 meseci) (Ivanov, 2010). Upravo zbog dugog trajanja i periodičnosti i ostavlja razarajuće posledice po psihu i opšte zdravlje žrtava.

\subsection{Vrste mobinga}

$\mathrm{U}$ zavisnosti od toga ko je mober, odnosno zlostavljač, a ko osoba nad kojom se vrši mobing, odnosno žrtva, postoji osnovna podela mobinga na (Kostelić-Martić, 2005):

1. Vertikalni mobing - pretpostavljeni je taj koji zlostavlja, tačnije vrši mobing nad jednim radnikom, ili mobira jednog po jednog radnika dok ne uništi čitavu grupu, ili, što je najređi slučaj jedna grupa radnika zlostavlja pretpostavljenog. Uništavanje čitave grupe, po sistemu jedan po jedan, naziva se još i strateški mobing

2. Horizontalni mobing - odvija se između radnika koji su po hijerarhijskoj lestvici na jednakom/istom položaju. Najčešće iz ljubomornih pobuda, ljubomore ili zavisti; a u cilju sopstvenog napredovanja u karijeri.

Osim ove dve, postoje još i:

- Verbalni mobbing (Živković, 2012) - javno ponižavanje ili omalovažavanje zaposlenog.

- Neverbalni - smišljeno i podmuklo zanemarivanje, ćutanje ili isključivanje.

- Strateški (Živkov-Ivanišević, 2001) - sa ciljem da se eliminiše jedan po jedan zaposleni kako bi se uništio čitav tim ili grupa. Uglavnom je to slučaj kad postoji veliki tehnološki višak, ili ako ne postoje objektivni razlozi da se otpuste nepodobni zaposleni.

- Bossing (Kostelić-Martić, 2005) - slučaj gde pretpostavljeni pokazuje jasan neprijateljski stav prema radniku, a to postiže vređanjem, ponižavanjem i agresivnim ponašanjem.

- Afektivni ili emotivni (Anon, Vrste i faze mobinga, 2011) - na ličnoj osnovi, a razlozi su ljubomora, zavist, zloba i antipatija. Svoju nesposobnost mober prikriva spletkarenjem i podmetanjima. 


\section{Mobing - zlostavljanje na radnom mestu}

Mobing je priča u kojoj na kraju nema pobednika. Mober sam po sebi pati od nekog oblika poremećaja ličnosti, a mobingovana osoba posledice nosi i trpi čitav život. Ono što doprinosi razvoju su obostrano osobine kako žrtve tako i "dželata“. Nastanku zlostavljanja takođe kumuju i loša organizacija poslovanja kompanije, preterano kompetitivna atmosfera unutar kompanije, loši međuljudski odnosi i nedostatak interne komunikacije, nezainteresovan menadžment i nekompetentna rukovodstvena struktura. $U$ takvim sistemima naglašena je briga $o$ ekonomskoj dobiti, bez stavljanja akcenta na međuljudske odnose.

\subsection{Aktivnosti mobinga}

Kao što je već bilo reči, aktivnosti mobinga traju dugo (6 ili više meseci) i dešavaju se vrlo frekventno (minimun jednom nedeljno). Krajnji cilj je prisiliti zaposlenog da napusti radno mesto, a $u$ međuvremenu ga poniziti, psihološki razoriti i ekonomski više degradirati.

Neke od aktivnosti kojima se mober bavi su: ogovaranje, ismevanje, klevetanje, širenje tračeva, direktno i indirektno vređanje, omalovažavanje, sramoćenje, kritikovanje, uskraćivanje prava na mišljenje, ignorisanje, davanje ili previše ili premalo radnih zadataka, vika, optužbe, napadi, nasrtaji, agresija, pa čak i seksualni napadi i ucene ${ }^{6}$.

Jasno je da je repertoar mobizirajućih postupaka i aktivnosti šarolik, ali može se klasifikovati u pet grupa, međusavnisno od efekta koji imaju na žrtvu, a grupe je odredio Laymann (Kostelić-Martić, 2005):

1. Napadi na mogućnost adekvatnog komuniciranja - situacija kada nadređeni ili kolege istog socijalno-poslovnog statusa ograničavaju izražavanje žrtve, uskraćujući joj pravo na komunikaciju i izražavanje stava.

2. Napadi na mogućnosti održavanja socijalnih odnosa - klasična izolacija. Žrtva je

\footnotetext{
${ }^{6}$ Prema (Slović \& Gigović, 2011): Podaci ispitivanja čemu su sve izloženi radnici na radnom mestu: verbalne pretnje i fizički napad (18\%), obezvređivanje rezultata rada (46), ismevanje zbog načina govora, držanja, hoda i odevanja (57), omalovažavanje zbog pola, nacionalnosti, socijalnog porekla i privatnog života (30), optužbe bez krivice (53), isključivanje iz društvenih aktivnosti (39), oduzimanje posla (4), pretrpavanje poslom (54), seksualno ugrožavanje $(0,6)$
}

poistovećena sa vazduhom, niti na nju neko obraća pažnju, niti joj se iko obraća.

3. Napadi na ličnu reputaciju - stvaranje lažne slike, širenje laži, ogovaranje, ismevanje, vređanje i ponižavanje.

4. Napadi na kvalitet profesionalnog rada konstantno prigovaranje, neosnovane kritike, opet vređanje i ponižavanje, preterano kontrolisanje i kažnjavanja. Žrtva mobinga dobija ili previse posla (sindrom punog stola žrtva se pretrpava radnim zadacima, rokovi za završetak prekratki, nema slobodne dane i uskraćen godišnji odmor) ili premalo (sindrom praznog stola - oduzimanje sredstava za rad, zadaci se dodeljuju drugima takozvana dekvalifikacija, žrtvi se dodeljuju zadaci koji od žrtve zahtevaju sposobnosti koje uglavnom nema. Sve u cilju da pogreši.).

5. Napadi na fizičko zdravlje - u ovom slučaju od žrtve se traži da obavlja zadatke koje ugrožavaju njeno zdravlje, preti joj se fizičkim napadima, a do njih često i dođe.

\subsection{Kako mombing utiče na osobu}

Bilo kakav vid agresije nije zdrav. Međutim, osoba nad kojom se vrši agresija trpi ogroman pritisak, često je pod stresom, i usled torture i maltretiranja zdravstveno oboli. Izloženost mobingu bitno ugrožava zdravlje žrtve. Opšte je prihvaćena podela u tri grupe, kako se dele smetnje i simptomi na zdravstveno stanje žrtve mobinga, kao što je prikazano u tabeli 1. (Nišević, 2007)

Mobing kod žrtava izaziva i bes, šok, nevericu šta se dešava i zašto baš njoj. Ubrzano im se razvija osećaj nezadovoljstva i bespomoćnosti, gube na samopouzdanju, pojačano su osetljivi, nervoza koja se javlja prilikom svakodnevnog odlaska na posao, povećana napetost i simptomi stresa, i na kraju smanjena produktivnost u izvršavanju zadataka.

Tabela 1 Smetnje i simptomi za zdravstveno stanje žrtve mobinga

\begin{tabular}{|l|l|}
\hline $\begin{array}{l}\text { Promene u } \\
\text { psihološkoj i } \\
\text { emocionalnoj } \\
\text { sferi }\end{array}$ & $\begin{array}{l}\text { Depresija, ankcioznost, krize } \\
\text { plača, osećaj depersonalizacije, } \\
\text { napad panike, socijalna izolacija, } \\
\text { emocionalna otupljenost }\end{array}$ \\
\hline
\end{tabular}




\begin{tabular}{|l|l|}
\hline $\begin{array}{l}\text { Promene na } \\
\text { telesno- } \\
\text { zdravstvenom } \\
\text { planu }\end{array}$ & $\begin{array}{l}\text { Glavobolja, poremećaj spavanja } \\
- \text { insomnija, vrtoglavica, problemi } \\
\text { sa varenjem, hipertenzija, srčani } \\
\text { problemi. }\end{array}$ \\
\hline $\begin{array}{l}\text { Promene u } \\
\text { ponašanju }\end{array}$ & $\begin{array}{l}\text { Agresivnost, pasivnost, letargija, } \\
\text { povećano konzumiranje poroka } i \\
\text { stimulansa - alkohol, droga, } \\
\text { cigarete, lekovi. }\end{array}$ \\
\hline
\end{tabular}

\subsection{Moberi}

Kako sama reč kaže, moberi su osobe koje vrše mobing. Psiholozi su se usaglasili da ovakve osobe definitivno pate od neke vrste poremećaja ličnosti, ali najizražajnije osećanje koje poseduju je duboko nezadovoljstvo i nesrećnost. U principu, oni sve što rade čine iz prostog razloga, da bi se osećali bolje. Takav vid satisfakcije ostvaruju tako što psihološki, moralno i na ostale srodne načine muče $i$ maltretiraju ljude oko sebe. Na taj način prikrivaju nemoć na nekom drugom polju svog privatnog života.

Psihološki profil ovakvih ljudi je krajnje začuđujući. To su uglavnom atraktivni, visoko obrazovani, elokventni ljudi. Izgledaju krajnje moćno i deluju prilično hrabro i samouvereno. Međutim, takve osobine krase i krajnje narcisoidne i egocentrične osobe. Oni muče druge zato što im to predstavlja zadovoljstvo, i imaju izraženo nizak nivo empatije. Obično su karakterno disproporcionalno onakvi za kakve se izraju, veoma su nesigurni i labilni, i u dubini duše potpuno nezadovoljni sobom. Po klasifikaciji su to najčešće psihopate ili sociopate, sa traumama i kompleksima iz detinjstva. Frustrirane su tuđim uspehom i trudom, a sami nemaju sposobnost da osete i pokažu poštovanje, uvažavanje ili naklonost. Demonstriranjem moći nad nekim ublažavaju sopstvene frustracije.

\section{4 Žrtve mobinga}

Za razliku od mobera, žrtve mobinga mogu biti i postati bukvalno svi. Profil osobe podobne da mober nad njom vrši torturu su uglavnom posvećeni ljudi, koji pošteno rade, trude se, kreativni su, prijatni i prijemčivi za rad. Čest slučaj je da su to i mlade osobe koje su tek počele da rade, sa željom da se dokažu i nauče posao, ali isto tako i osobe pred penzijom, hendikepirane i bolesne. Poenta je da mober ne bira svoje „izabranike“. Takođe, ne postoji precizna statistika da li pol ima udela u takozvanom odabiru, ali kako sada stvari stoje žene su u opasnijoj grupi. A kada su u pitanju profesije i delatnosti, gotovo su izjednačeni procenti.

Gotovo savršena žrtva mobinga se razlikuje od drugih po svojim sposobnostima i potencijalu, a ima i izražen osećaj za pravdu. Upravo zbog toga, kada se nađe u procesu zlostavljanja u početku je krajnje zbunjena $\mathrm{i}$ ne razume razloge za takve akte $\mathrm{i}$ ponašanja. Tek kada teror uzme maha, žrtva biva psihički slomljena i pregažena. Cenu „plaćaju“ razorenim zravljem, karijera im je uništena ili drastično usporena, finansijski slabe, a psihološki rat gube usled osećaja bespomoćnosti i ne pronalažena izlaska iz takve situacije. Da sve bude još gore, trpi i njihov emotivni i porodični život. Posledice su uglavnom dugoročne i trajne.

\subsection{Načini sprečavanja i borbe protiv mobinga}

lako se danas mnogo više javno spominje, termin mobing je za mnoge još uvek nepoznanica. Naime, ljudi shvataju da se radi o zlostavljanju na radnom mestu, ali u velikom broju ne znaju šta se sve pod tim podrazumeva, koja su im prava i kako da se brane u slučaju da postanu žrtve mobera. $S$ tim $u$ vezi, potrebno je neprekidno upozoravati ljude da mobing shvate ozbiljno, da blagovremeno reaguju u slučaju da postanu žrtve, pojasniti im pravna rešenja i kakve su kazne predviđene za mobere, ali pre svega toga svaka organizacija mora da organizuje sopstvene mere prevencije. $U$ prvom redu su informisanje i edukacija. Načini sprečavanja i borbe protiv mobinga (Nišević, 2007):

- Prevencija - sprečiti konflikte da eskaliraju u zlostavljanje i teror. Potrebna je edukacija menadžera na svim nivoima, posebno celog menadžmenta ljudskih resursa. Jasno ustanoviti politiku kompanije, kao i pravila u slučaju dolaska u konflikt.

- Intervencija menadžmenta - bilo bi dobro da u svakoj organizaciji se odredi bar jedna osoba za kontak i savetovanje zaposlenih. Potrebno je takođe i to jasno objaviti i informisati ljude ko je ta osoba, i osigurati odnos poverenja obezbeđujući diskreciju.

- Zakon - zakonske mere i propisi možda i najviše i najbolje pomažu borbu protiv mobinga. Poenta je da se zakonima obezbedi pravo zaposlenog na fizičko i psihičko zdravlje na poslu. 
Veoma je važno da se borba protiv mobinga sprovodi svuda u svetu na visokom društvenom nivou. Način kako to postići su mediji, svi raspoloživi, i efektivno i efikasno zakonodavstvo svake zemlje ponaosob.

\title{
Ako biste saznali za postojanje slučajeva mobinga na poslu i poželeli da ih prijavite, kome biste prijavili?
}

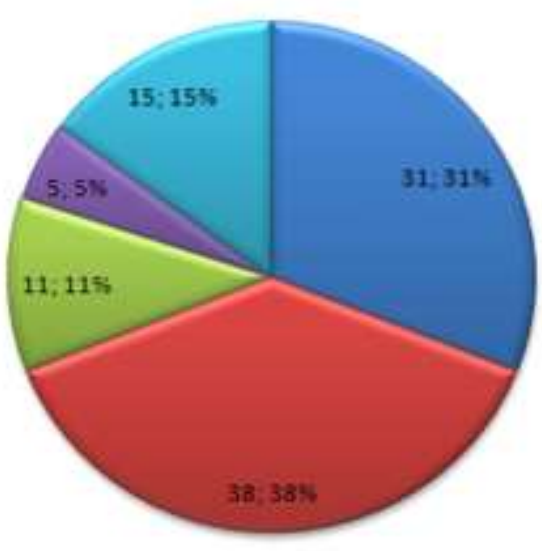

\author{
Agencifiza borbu protiv \\ mibinga \\ a Policiji \\ U sudstwu \\ Nikom ništa ne bih rpijavio \\ U Podneo bih anonimnu prijavu
}

Slika 1 Internet anketa

U Srbiji je takođe donet Zakon o sprečavanju zlostavljanja na radu (Zakon, 2010), i zabranjuje bilo kakav vid zlostavljanja kao i zloupotrebe prava zaposlenih $^{7}$. Osim toga predviđa i kaznene mere za mobere.

Pored Zakona, izdat je i Pravilnik o pravilima ponašanja poslodavaca i zaposlenih, u vezi sa prevencijom i zaštitom od zlostavljanja na radu (Pravilnik, 2010). Donošenjem ovakva dva zakonska akta, podigla se i svest poslodavaca, zaposlenih kao i sindikata radnika ${ }^{8}$. Sve je više edukacija kako bi se umanjio mobing i zlostavljanje.

Ne može se zaobići činjenica da su se mobingom poslodavci služili baš zbog ostvarivanja što većih prihoda, međutim, dešava se upravo suprotno. $U$ atmosferi gde obitava mobing, produktivnost se drastično smanjuje, na šta ne reaguju samo žrtve

\footnotetext{
7 Osim za zaposlene, odnosi se i na honorarce, privremeno zaposlene, pripravnike, lica na stručnom usavršavanju ili praksi, volonteri, sve osobe koje imaju udela u poslovanju preduzeća, na bilo koji način.

8 Prema Pravilniku, obaveze radnika su: obaveza da ne mobinguje druge, da se prema kolegama ponaša sa poštovanjem, uvažavanjem i dostojanstvom; dok su obaveze poslodavaca: da zaštite radnike od mobinga, stvore uslove za zdravu i bezbednu radnu okolinu, da sprečava mobing, da obezbedi informisanje zaposlenih šta je a šta nije mobing $\mathrm{i}$ tako dalje. (Pušonjić \& $\mathrm{i}$ drugi, 2010)
}

mobinga direktno, već i ostalo radno zaposleno osoblje. Prvenstveno što gube motivaciju za rad, a drugo usled stresova razvijaju i otpor prema radu. Sa druge strane, mobing izaziva gubitke i visoke troškove za kompaniju. Naime, bolovanja i odsustvovanja sa posla koštaju i firmu u kojoj žrtva radi. Takođe se odražavaju uticaji i na nacionalnu ekonomiju: u zdravstvu rastu troškovi za obezbeđeno lečenje i rehabilitaciju mobingovanih, ekonomski - usled otkaza radnika (bilo da su ga dobili, ili sami dali) svi završavaju na birou, što košta državu zbog isplate naknada za nezaposlene. Slično je i sa tehnološkim viškom, dok se čak promena oseća i u okviru PIO fonda, pošto zbog loše situacije mnogo više radnika prevremeno odlazi u penziju, ili šalje zahtev za invalidske. Prema nekim pokazateljima, mobing države može da košta i do nekoliko milijardi evra godišnje, kad se sve sabere.

U svakom slučaju, za žrtvu mobinga je važno da u svrhu borbe protiv napasnika, odnosno mobera, redovno skuplja materijalne dokaze, kao što su poruke, dopisi, mailovi, faksovi, ugovori i ostala dokumenta. Gledati da ima svedoka prilikom napada, kako bi se na njih mogli pozvati u slučaju potrebe odbrane i dokazivanja zlostavljanja. Voditi najbolje pismenu evidenciju svih vrsta napada, i to zapisivati sve pojedinosti, datum, vreme, mesto, 
prisutne osobe, način mobingovanja. Takođe šta je bitno uraditi, obraditi se određenoj osobi u okviru službe menadžmenta, najčešće je to sektor menadžmenta ljudskih resursa; kao i ustanovi koja se bavi ovim pitanjima. Nakon svega toga, za privatan život i dobrobit žrtve, najpametnije je da se obrati nekom psihologu ili psihijatru, kako bi se započelo lečenje i najpre oporavak nakon mučnog zlostavljanja.

U okviru jednog istraživanja na Internetu (Ćosić, 2011) zanimljivo je kako su ispitanici odgovorili na pitanje kome bi se obratili u slučaju mobinga. Rezultati ankete su prikazani na slici 1.

\section{ZAKLJUČNA RAZMATRANJA}

Ljudsko društvo i ljudska zajednica od kada postoji prisutni su različiti vidovi ponižavanja, maltretiranja, zlostavljanja, maltretiranja i terorisanja. Osim u privatnim sferama, svako razdoblje imalo je svoj „doprinos" na polju mobinga, odnosno zlostavljanja na radu. Nekada je preovladavalo fizičko kažnjavanje, međutim, kako je vremenom fizičko nasilje bivalo društveno neprihvatljivo, mahom su poslodavci krenuli da psihološki kažnjavaju i ugnjetavaju zaposlene. Na nesreću, to nije jedini kanal zlostavljanja. Konkurencija i česte ekonomske krize, uticale su negativno na odnos kolege sa kolegom, pa se polako razvio i mobing u smeru osoba na istoj društvenoj lestvici ili spisku za platu.

lako se mobing vezuje isključivo za radnu, odnosno poslovnu sredinu; u suštini radi se o poremećenoj komunikaciji i međuljudskim odnosima među ljudima u poslovnoj jedinici. Osim posledica od kojih dugoročno pati pojedinac, mobing situacije se energetski reflektuju i na radno okruženje i grupe zaposlenih u okviru radne zajednice. Međutim, tu se štetno dejstvo mobinga ne završava. Stres koji prouzrokuje, loša osećanja i strah, svakodnevno ostavljaju traga na ljudima, što ih koči i uslovljava u svakodnevnim aktivnostima.

Sa psihološkog apsekta posmatrano, potrebu za moći prisutna je kod većine ljudi. Kao i potreba za napredovanjem i stalnim dokazivanjem. Međutim, kada kompeticija postane patološka potreba, često ide u krajnost. Tanka je linija gde etika prestaje a počinje mobing. Kao što se moglo i pretpostaviti, lice koje odabere da se služi mobingom, i maltretira i zlostavlja druge, gotovo je sigurno da pati od neke vrste poremećaja. Poenta je znati ih prepoznati i sa njima se izboriti.

Mobing nije naivna pojava, i treba ga shvatiti krajnje ozbiljno. Potrebno je što bolje se informisati na ovu temu, kako bi žrtva znala koje su joj opcije ako dođe do borbe sa ovom nemani. Najgore od svega je što zlostavljanje kao takvo ostavlja traga na psihofizičko zdravlje pojedinca, i ne samo na njega, već i na radno okruženje, socijalnu sredinu i porodicu kao nukleus. Kako je mobing atak na suptilnu i tananu dušu čoveka, osim duševne patnje, udara se na lični integritet, dostojanstvo, moral, sisteme vrednosti, kulturu, gotovo sve pozitivne stvari koje žrtva poseduje. Postavlja se pitanje koliko je pametno obraćati pažnju na faktor vreme, pošto je potrebno da prođe određen interval vremena da bi se detektovao mobing kao pojava, i ustanovilo njegovo postojanje. Za to vreme žrtva pati, i njen oporavak je krajnje neizvesna kategorija. Da li je potrebno čekati šest meseci da prođe kako bi se mobing nazvao zlostavljanjem, možda tad za žrtvu bude ipak prekasno.

lako situacija nije bajna, pošto se broj slučaja zlostavljanja rapidno povećava iz dana u dan, ipak se mora gledati pozitivno u budućnost. $S$ tim u vezi potrebno je posvetiti pažnju u okviru svake firme i/ili organizacije, uspostaviti pravila ponašanja, razvijati toleranciju na radu, služiti se kanalima informisanja, obavljati raznovrsne edukacije, organizovati treninge za komunikacione veštine, uspostaviti bolju kontrolu menadžmenta i koristiti se zakonskom regulativom i u praksi. lako se danas mnogo govori o problemu psihološkog terora na poslu, alijas mobingu, čini se da je proučavanje te pojave tek u ekspanziji. Što jeste pozitivna stavka, međutim, ipak se dođe do toga da je neophodno da zakonodavstvo svake zemlje odlučnije rešava ova pitanja. Jer, na kraju krajeva, zlostavljanje na radu je istorijska činjenica, koju nije moguće u potpunosti iskoreniti, ali je jeste moguće sprečiti.

\section{Citirani radovi}

Anon. (2009, 03 17). Mobing - istina o kojoj se malo govori. Retrieved from elef web magazin: http://www.elefmagazin.com/Lifestyle/Mobing-istina-o-kojoj-se-malo-govori.html

Anon. (2010). Mobing. Retrieved from Vikipedija Slobodna enciklopedija: http://sr.wikipedia.org/sr/Mobing 
Anon. (2011, 12 07). Mobing u svetu. Retrieved from Stop mobing: http://mobing.rs/articles.php?article_id=14 Anon. (2011, 12 07). Šta je mobing? Retrieved from Stop mobing: http://mobing.rs/articles.php?article_id=1 Anon. (2011, 12 07). Vrste i faze mobinga. Retrieved from Stop mobing: http://mobing.rs/articles.php?article_id=2 Anon. (2012). Mobing i kako ga sprečiti Priručnik za regionalne poverenike UGS "Nezavisnost". Retrieved from GS PUT Nezavisnost: http://www.gsputnezavisnost.org.rs/nuke/materijali/ISCOD_V_-_Mobing_i_kako_ga_spreciti_-_Prirucnik.pdf Ćosić, M. (2011, 11 13). Novinarski osvrti na dešavanja ... Retrieved from wordpress: http://marijacosic.wordpress.com/2011/11/13/mobing-zlostavljanje-na-radnom-mestu

Gvozdić, A. (2010). Pasivna agresivnost. Retrieved from Akademija uspeha: http://www.akademijauspeha.com/clanci_svi/Pasivna\%20agresivnost.html

Ivanov, Z. (2010, 09 03). Zlostavljanje se može izmeriti. Retrieved from Politika online: http://www.politika.rs/rubrike/Stada-se-radi/Zlostavljanje-se-moze-izmeriti.lt.html

Kondić, V., \& dr, i. (2011). Mobing i zaštita od mobinga. Retrieved from Društvo psihologa Srbije: http://www.dps.org.rs/seminari/mobing-i-zatita-od-mobinga

Kostelić-Martić, A. (2005). Mobing: psihičko maltretiranje na radnom mjestu (kako prepoznati mobing, kako se odbraniti i kako ga sprečiti). Zagreb: Školska knjiga.

Nišević, B. (2007, 02 05). Projekat: Mobing kao vid patološke komunikacije. Retrieved from Scribd: http://www.scribd.com/doc/92966/Mobing

Popić, M. (2012, 09 04). Manipulacija - laskanje, vređanje i druge metode. Retrieved from psihološki kutak - Psihološko Online savetovalište: http://www.psiholoskikutak.com/manipulacija-laskanje-vredanje-i-druge-metode/

Pravilnik. (2010). Pravilnik o pravilima ponašanja poslodavaca i zaposlenih u vezi sa prevencijom i zaštitom od zlostavljanja na radu. Službeni glasnik Republike Srbije, br. 62. Retrieved from

http://www.paragraf.rs/propisi/pravilnik_o_pravilima_ponasanja_poslodavaca_i_zaposlenih_u_vezi_sa_prevencijom_i_zas titom_od_zlostavljanja_na_radu.html

Pušonjić, D., i drugi. (2010, 09 03). Za zlostavljanje na poslu visoke kazne. Blic, pp. http://poslovi.infostud.com/vesti/Zazlostavljanje-na-poslu-visoke-kazne/52/16336/.

Slović, A., \& Gigović, B. (2011, 05 23). Mobing trpi svaki drugi radnik. Retrieved from Blic online: http://www.blic.rs/Vesti/Drustvo/255463/Mobing-trpi-svaki---drugi-radnik

Zakon. (2010). Zakon o sprečavanju zlostavljanja na radu. Službeni glasnik Republike Srbije, br. 36. Retrieved from http://www.paragraf.rs/propisi/zakon_o_sprecavanju_zlostavljanja_na_radu.html

Živković, T. (2012, 01 13). Mobing: Psihičko zlostavljanje na radu. Retrieved from Preko ramena - onlajn časopis: http://www.prekoramena.com/t.item.382/mobing-psihicko-zlostavljanje-na-radu.html

Živkov-Ivanišević, M. (2001, 04 21). Mobing - zlostavljanje radnika. Retrieved from mcb blog: http://www.mcb.rs/blog/2011/04/21/mobing-\%E2\%80\%93-zlostavljanje-radnika/

Datum prve prijave:

Datum prihvatanja članka:
20.09.2012.

16.11.2012.

\section{Kako citirati ovaj rad?}

\section{Style - APA Sixth Edition:}

Ćurčić, R., Prebiračević, V., \& Vasić., N. (2013, 01 15). Manipulacija savremenim komunikacijama u svrhu mobinga. (Z. Čekerevac, Ed.) FBIM Transactions, 1(1), 74-84. Retrieved from www.meste.org/fbim/FBIM 1 2013/ 08.pdf. doi: 10.12709/fbim.01.01.01.08

\section{Style - Chicago Fifteenth Edition:}

Ćurčić, Radmila, Vladimir Prebiračević, and Nataša Vasić. "Manipulacija savremenim komunikacijama u svrhu mobinga." Edited by Zoran Čekerevac. FBIM Transactions (MESTE NVO) 1, no. 1 (01 2013): 74-84.

Style - GOST Name Sort: 
Curčić R. i dr. Manipulacija komunikacijama u svrhu mobinga

FBIM Transactions Vol.1 No.1 pp. $93-102$

Ćurčić Radmila, Prebiračević Vladimir and Vasić. Nataša Manipulacija savremenim komunikacijama u svrhu mobinga [Journal] = Manipulacija komunikacijama u svrhu mobinga // FBIM Transactions / ed. Čekerevac Zoran. - Beograd : MESTE NVO, 01 15, 2013. - 1 : Vol. 1. - pp. 74-84.

Style - Harvard Anglia:

Ćurčić, R., Prebiračević, V. \& Vasić., N., 2013. Manipulacija savremenim komunikacijama u svrhu mobinga. FBIM Transactions, 15 01, 1(1), pp. 74-84.

Style - ISO 690 Numerical Reference:

Manipulacija savremenim komunikacijama u svrhu mobinga. Ćurčić, Radmila, Prebiračević, Vladimir and Vasić., Nataša. [ed.] Zoran Čekerevac. 1, Beograd : MESTE NVO, 01 15, 2013, FBIM Transactions, Vol. 1, pp. 74-84. 